マーケティング・エクセレンスを求めて

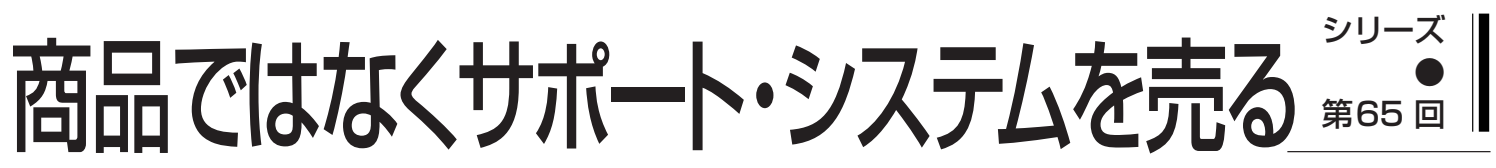
〜マイクロダイエ卟の事業規定〜

\title{
〔サニーヘルス株式会社 マイクロダイエット〕
}

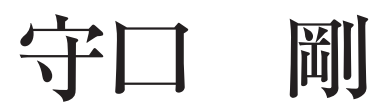

早稲田大学 商学学術院教授
中村 哲

○有限会社中むら 代表取締役

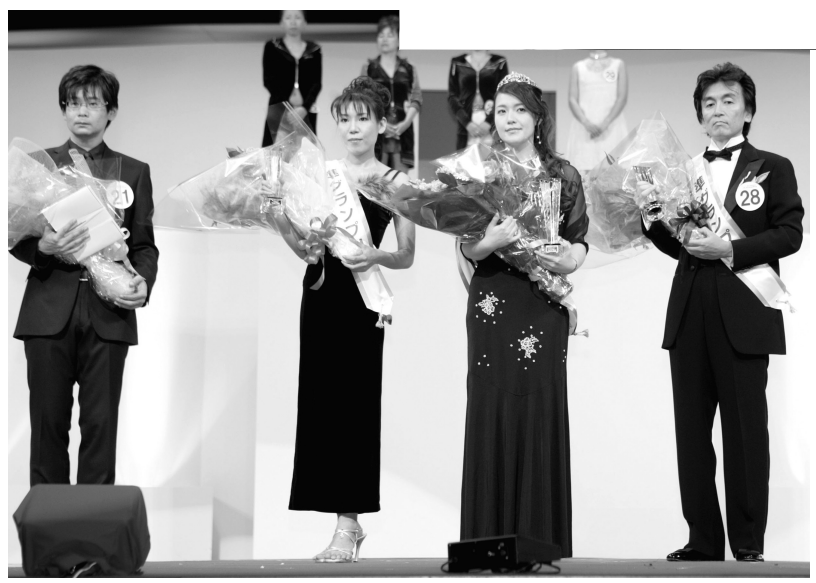


(1)

はじめに

JR 山手線をよく利用する人であれば，車内 モニターでマイクロダイエットの広告を見た ことがあるだろう。この広告では，マイクロ ダイエット・グランプリと呼ばれるコンテス トの様子や出場者の体験談などを中心に，マ イクロダイエット利用者のダイエット過程と その効果を伝えている。マイクロダイエット によって実際に減量に成功した利用者が出演 することによって, その訴求内容についての 説得力が増すと同時に，ダイエットを考えて いる人に，自分にもできそうだと思わせる効 果をもたらしている。

マイクロダイエットは, 健康関連商品の販 売を事業とするサニーヘルス株式会社が販売 するダイエット食品である。利用者は食事の 代わりにマイクロダイエットを利用すること によって，必要な栄養をとりながら摂取カロ リーを抑えることができる。ダイエット食品 にはいろいろなタイプのものがあるが，マイ クロダイエットは, 食事代替型カロリー調整 食品として位置づけられる。マイクロダイエ ットはこのタイプのダイエット食品のパイオ ニアであり，この市場において圧倒的なシェ アを獲得している。

ここ $1 \sim 2$ 年の間に, 食事代替型カロリー 調整食品の市場には, 有力企業の参入が相次 いでいる。キリンビールの $100 \%$ 子会社であ るキリンウェルフーズは，2005年に「リエー 夕」のリニューアルを行うとともに，ブログ を利用したコミュニティサイトを立ち上げ， 売上を大きく伸ばした ${ }^{1)} 。 2006$ 年には，森永
製菓が「ウィダー・ダイエットサポート」を， アサヒビール子会社のアサヒフードアンドへ ルスケアが「スリムアップスリム」を，サン トリーが「ダイエッツ」を，それぞれ発売し た。森永製菓はウイダー・ダイエットサポー トの専用サイトを開設し, 製品の利用者同士 の座談会や体験日記を掲載している。スリム アップスリムにも会員制のコミュニティサイ トがあり，利用者間相互の交流がなされる仕 組みを提供している。サントリーは，ダイエ ッツを「ヘルシーダイエットシステム」と位 置づけ，ユーザー間の交流に加えて，専門家 からのアドバイスの提供に力を入れている。

これらはいずれも, ユーザー間の交流やア ドバイスなどを通じて，ダイエットという行 為を継続させるための仕組みづくりを意眓す るものである。後述するように, ダイエット 食品という商品を販売するだけでなく, 継続 のための仕組みを提供することは，マイクロ ダイエットを成功に導いた重要な要因である。 後発の各企業がそうした仕組みを習ってこの 市場に参入してきていることは，何よりもそ の仕組みの有効性と重要性を物語っていると 思われる。

ダイエットは，おいしいものを食べたいと いう欲求を我慢することによって実現できる ものであり，食欲という人間の本能に逆らう 行為でもある。また，ダイエットの効果は即 時的に現れるわけではなく，ある程度の期間 にわたって努力を継続することが求められる。 これらの理由から, 効果が実感できるまでの 過程で挫折しやすいという性質を持っている。 ダイエットを実行したいと考える人，実際に 試してみる人は多くても, 行動を継続し目標 
を達成する人は少ないのが現実である。この 点に加えて, 無理なダイエットによって健康 に悪影響が生じるというようなケースもある。 こうしたことが, ダイエットという行為の難 しさであり, ダイエット・ビジネスの課題で もある。

マイクロダイエットの成功の大きな要因は, 商品というモノだけを販売するのではなく, ダイエットを安全に継続させるための仕組み もあわせて提供したことに求められる。サニ ーヘルス社は, マイクロダイエットの事業を, ダイエット食品の販売と捉えるのではなく, ダイエット・サポート・ビジネスだと規定し ている。このことが，マイクロダイエットの 事業としての継続的な成功と成長をもたらす 原動力となってきたのである。

\section{(2)}

\section{ダイエット市場におけるマイクロダ} イエットの位置づけ

ダイエット市場における主要な顧客は若い 女性であるが，中高年の女性および男性の利 用者も増加している。図表一1は, マイクロ ダイエットも含むダイエット・サプリメント

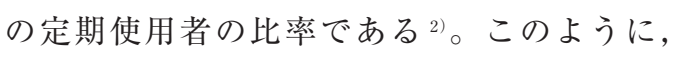
20 代女性の数值が最も高いものの, 20 代〜

\section{口图表-1}

ダイエット・サプリメントの利用率（\%）

\begin{tabular}{|r|r|r|r|r|r|r|}
\hline & 10 代 & 20 代 & 30 代 & 40 代 & 50 代 & 60 代 \\
\hline 男性 & 0.0 & 4.4 & 5.8 & 3.5 & 5.3 & 1.2 \\
\hline 女性 & 10.0 & 14.6 & 11.8 & 13.9 & 5.3 & 6.5 \\
\hline
\end{tabular}

出所：日本能率協会総合研究所『健康ニーズ基本調查 2004』
40 代の女性で $10 \%$ を超える定期使用者が存 在している。男性においても，30 代および 50 代で $5 \%$ を超える定期使用者が存在している。 2003 年の厚生労働省「国民健康・栄養調査」 の結果をみると, 男性の 30 代〜 60 代の各代 における肥満者の割合がいずれも $30 \%$ 超え ている ${ }^{3)}$ 。10 年前の各年代の肥満比率はいず れも20\%台であり, 男性の肥満者の割合は 10 年間で大幅に上昇している。また，女性に おいても 60 代の肥満者比率が $30 \%$ を超えて いる。こうした現状を背景として, 男性の各 年代および女性の中高年のダイエットへの関 心は確実に向上している。ダイエット市場の 中心顧客は若い女性であるが，近年では中高 年男女の利用もすすみ, 市場が拡大してきて いる。そして，マイクロダイエットは，その 市場拡大にも大きな役割を果たしている。

ダイエット食品と一口に言っても成分や形 態でみたさまざまなタイプが存在する。マイ クロダイエットを代表とするカロリー調整食 品もその一つであるし, 例えば糖分吸収の抑 制成分をもつサプリメントもある。ダイエッ 卜食品の定義にはさまざまな考え方があり， また，定義の仕方によって算出される市場規 模も異なってくる。ここでは, ダイエット食 品市場を, 健康食品とサプリメントのうちダ イエット訴求がなされている商品からなる市 場だと考えよう。

上記の基準でみたダイエット食品の市場規 模の推移は図表一 2 に示される ${ }^{4)}$ このように， 市場規模は毎年拡大し続けており，2004年に は 1000 億円を超えるまでに成長している。ダ イエット食品のなかでも, 食事代替型カロリ 一調整食品が大きなウェイトを占めており， 
図表一 2

ダイエット食品市場規模の推移（単位：百万円）

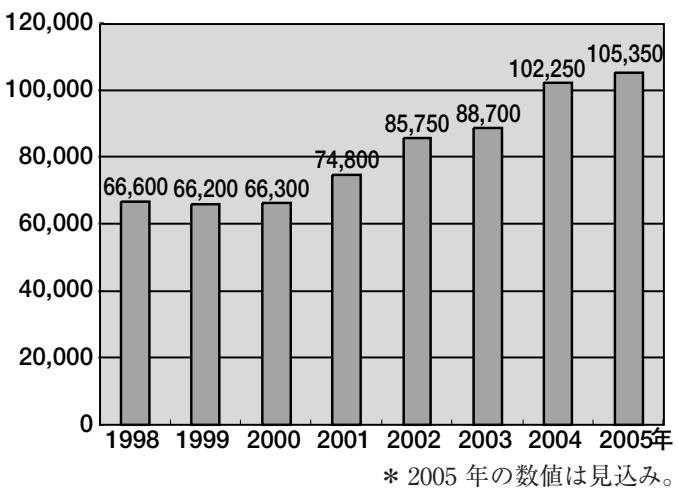

出所：富士経済『H・B フーズマーケテイング便覧 2006 年 No.2』

図表-3

ダイエット食品市場におけるカロリー調整食品の構成比

\begin{tabular}{|l|r|r|}
\hline & \multicolumn{1}{|c|}{2004 年 } & 2005年 (見込み) \\
\hline 販売金額 (百万円) & 49,450 & 52,250 \\
\hline 構成比 $(\%)$ & 48.4 & 49.6 \\
\hline
\end{tabular}

出所：富士経済『H・B フーズマーケテイング便覧 2006 年 No.2』

図表ー 3 に示されるように，2004 年の売上構 成比は $48.4 \% ， 2005$ 年（見达み）のそれは $49.6 \%$ に達している。上述のように，マイク ロダイエットもカロリー調整食品の1つに位 置づけられる。

図表一2のダイエット食品の市場規模推移 をみると，特に 2003 年から 2004 年にかけて 市場が大きく成長している。これは，上述し たカロリー調整食品，特にマイクロダイエッ トの伸びに依存する部分が大きい。図表一 4 は，サニーヘルス社の売上推移を示している が，2003 年から 2004 年にかけて売上を大き く伸ばしていることが分かる。サニーヘルス 社の売上のかなりの部分はマイクロダイエッ トが稼いでいる。これらのことから，マイク ロダイエットの売上拡大とダイエット食品全
図表一 4

サニーヘルス株)の年度別売上推移（単位：百万円）

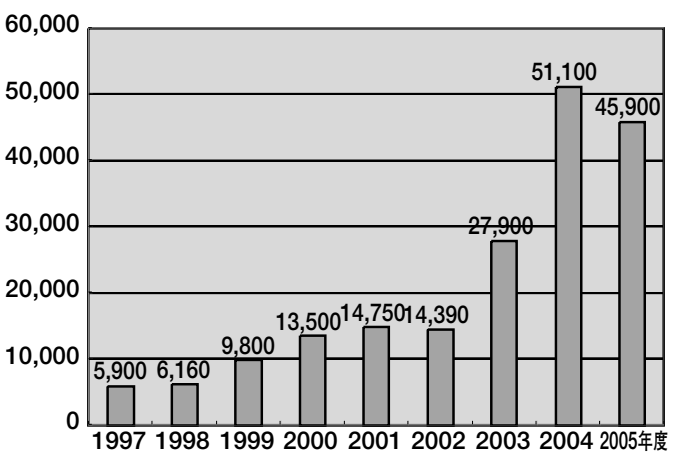

出所：サニーヘルス株式会社ホームページ

図表- 5

マイクロダイエットの市場シェア

\begin{tabular}{|l|r|r|}
\hline & 2004 年 & 2005年(見込み) \\
\hline ダイエット食品市場におけるシェア $(\%)$ & 35.7 & 35.3 \\
\hline カロリー調整食品場におけるシェア(\%) & 73.8 & 71.2 \\
\hline
\end{tabular}

出所:富士経済『H・B フーズマーケテイング便覧 2006 年 No.2』

体の売上拡大がリンクしていることが確認で きる。

マイクロダイエットの市場シェアは図表一 5 に示される。ダイエット食品市場全体に占め る 2004 年の市場シェアは $35.7 \% ， 2005$ 年の シェア（見込み）は $35.3 \%$ とっている。さ らに，2004 年のカロリー調整食品市場におけ る市場シェアは，実に $73.8 \%$ という数值とな っている。同市場における 2005 年のシェア （見达み）は $71.2 \%$ と若干の減少となってい る。また，サニーヘルス自体の売上推移をみ ても，2004 年度から 2005 年度にかけて若干 の減少がみられる。この理由としては，2004 年度に大幅に売上が増加したことによる反動 や有力な競合製品のリニューアルによる売上 拡大などが考えられる。それでも，カロリー 調整食品市場において 7 割以上のシェアを確 
保していることは，マイクロダイエットの市 場における強固な地位を現している。

上記のように，マイクロダイエットは，ダ イエット食品市場において, 自らの売上を伸 張させるとともに, 市場全体のパイの拡大に も大きな貢献を果たしてきた。ダイエット食 品市場における牽引車の役割を担ってきたと いうことができるだろう。

\section{(3)}

\section{サニーヘルスの歴史と事業理念}

サニーヘルスは，もともとは長野県で健康 飲料・食品を販売しており，1978 年にサニー ヘルス株式会社として法人化された。翌 79 年 には「グルコマンナン」という站蒻を主成分 とした商品を訪問販売で売りはじめた。この 商品は，長野県内で大きな売上をあげ成功し たものの，半年たっても瘦せないなどという クレームがつづき，以前からの顧客をも失う ことになってしまったという。

その後, 新商品として「6ヶ月間減量作戦」 と称する, 商品と教材, 専門家によるアフ夕 ーフォローをパッケージにしたものを販売し たところ，減量成功者が徐々に増え始めてき た。創業者の西村社長は, このときの経験か ら，「ダイエット・ビジネスは物売りではな く, いわば教育産業である。売りっぱなしで はなく，効果が出るまで支援していく事業で ある」という理念を有するに至ったという。

イギリスのユニバイト総本社から，マイク ロダイエットの話がサニーヘルスに持ち达ま れたのは 1987 年のことであった。マイクロダ イエットは, 英国サリー大学のジャクリー
ヌ・ストーディ博士によって 1983 年に開発さ れた食事代替型の肥満解消減量食である。1 日に必要な栄養素約 50 種類を含みながら, 摂 取カロリーが大幅にカットできる食品であり， 英国での臨床デー夕もそろっていた。サニー ヘルスでは, 英国での臨床デー夕や体験集を もとにして，日本で 100 人のモニターによる テストを実施したところ，体重を低減させる 効果を確認するとともに, 瘦せることによっ て体調が向上するという効果をも確認したと いう。この結果, 日本国内独占販売権を取得 し，日本人向けの味，カロリー等にアレンジ した上で，1989年に販売を開始した。

事業を展開していくとともに，マイクロダ イエットの日本国内での効果について大学及 び研究所での研究を実施し, 1993 年頃からそ の成果を学会誌, 学会などに継続的に発表し ている。これらの研究では, 減量効果だけで はなく，生活習慣病に対する効果，睡眠呼吸 障害などとの関係なども採り上げられている。 また，いくつかの医療機関において，健康管 理, 肥満外来, 糖尿病外来の患者に実際にマ イクロダイエットを利用してもらい，その効 果を確認している。こうした成果は, サニー ヘルスが医師・医療従事者に発行している情 報紙である「MD UPDATE！」で紹介して いる。

このように，マイクロダイエットの事業の 土台には，商品を売るのではなく，ユーザー がダイエットという目的を達成することを支 援する，というダイエット・ビジネスに対す る捉え方がある。そして，このことが土台と なって，後述するようなマーケティング・ミ ックスの有機的な連動がなされている。 
(4)

マイクロダイエットのマーケティング

\section{1. チャネル}

マイクロダイエットの当初の販売チャネル としては，エステティックサロンが選択され た。これは,ダイエットの失敗者を出さない という観点から選ばれたものである。エステ ティックサロンの利用客は定期的に通うこと が前提となるため，顧客に対する十分なカウ ンセリングが可能となる。さらに，エステテ イックサロンの中でも真剣に取り組んでくれ るところをパートナーとするために, 取引条 件を厳しく設定した。初回の仕入れ金額の下 限を設定するとともに，月々の加盟料を徵収 し，一泊二日の研修も義務付けた。こうした ことによって, エステ経由でマイクロダイエ ットを購入した利用者のなかのダイエット成 功者が増加し， 口コミによって顧客がひろが ってきた。

翌年の 1990 年からは，薬局にチャネルを拡 大していくが，ここでもダイエットの成功率 を維持するために, 厳しく取引条件を設定し た。90 年 6 月には講談社の女性誌「MINE」 にパブリシティ記事が掲載され，30万部の発 行に対して 1 万人の購入者を得ることができ た。この経験によって，女性誌を広告媒体と して通信販売のテストを行い，1992 年から本 格的に通信販売を展開してきた。

通信販売での注文は電話を主体としてきた。 SUNNY SHOP というネット上の通販サイト を立ち上げた後しばらくの間も，マイクロダ イエットだけは電話による販売のみに限定し てきた。これは，販売に際して，単に注文を
取るだけでなく, 顧客の健康状態やダイエッ トの動機などを把握し, 利用方法などを丁寧 に説明するためである。なお，現在ではWeb サイト上で，後述するようなさまざまな情報 提供を行うとともに，ネットを通じた通信販 売も行っている。

\section{2. 商品と価格}

商品は 1 食分ずつパッケージされており， ドリンクタイプとスープタイプがある（2006 年 2 月から, リゾット，弁当，ゼリーなどの 新商品も発売)。14 食分が 1 箱として販売さ れており，ドリンクタイプには 7 つ味種が, スープタイプには 4 つの味種がある。価格は, 14 食分で 16,800 円（税抜き）に設定されてい る。最低 4 箱を使用して効果がでるとのこと で, 効果を出すためには 4 箱分の料金, 67,200 円の費用がかかることになる。この価格設定 は，商品のコストだけではなく，購入者がダ イエットに成功するためのサポート提供コス トや，製品改良のための研究開発コストを見 込んで設定されたものである。

図表一 6 は，主な競合商品との比較である。 いずれの商品も減量を目的とした商品であり， 食事代替型のカロリー調整食品である。缶入 りの米国製のマイクロダイエット以外はどの 商品も一食ずつの袋入りとなっており, 商品 パッケージのイメージも似通ったものである。

価格は，サニーヘルスのマイクロダイエッ トが最も高く，ほとんどの製品の 2 倍から 3 倍の設定となっている。上述のように, マイク ロダイエットの価格は, サポートのための仕 組みやッールなどが含まれた設定となってい る。次にそのサポートの仕組みをみてみよう。 
図表一 6

主な競合製品と販売価格

\begin{tabular}{|c|c|c|}
\hline 商品名 (企業名) & \multicolumn{2}{|c|}{$\begin{array}{l}14 \text { 食換算価格 } \\
\text { (税抜き) }\end{array}$} \\
\hline $\begin{array}{l}\text { マイクロダイエット } \\
\text { (サニーヘルス) }\end{array}$ & & 16800円 \\
\hline $\begin{array}{l}\text { パーフェクトダイエット } \\
\text { (アドバン) }\end{array}$ & $\begin{array}{l}\text { 初回 } \\
\text { 以降 }\end{array}$ & $\begin{array}{l}6000 円 \\
8000 円\end{array}$ \\
\hline $\begin{array}{l}\text { スタンダードダイエット } \\
\text { (みやび) }\end{array}$ & & 5800円 \\
\hline $\begin{array}{l}\text { リエータ } \\
\text { (キリンウェルフーズ) }\end{array}$ & $\begin{array}{r}\text { 5食分 } \\
\text { 14食換算 }\end{array}$ & $\begin{array}{l}2500 円 \\
7000 円\end{array}$ \\
\hline $\begin{array}{l}\text { マイクロダイエット } \\
\text { (米国製) }\end{array}$ & $\begin{array}{r}10 \text { 食分 } \\
14 \text { 食換算 }\end{array}$ & $\begin{array}{l}\text { 3980円 } \\
5572 \text { 円 }\end{array}$ \\
\hline $\begin{array}{l}\text { ウィダー・ダイエットサポー } \\
\text { ト(森永製菓) }\end{array}$ & & 5000円 \\
\hline $\begin{array}{l}\text { スリムアップスリム (アサヒ } \\
\text { フードアンドヘルスケア) }\end{array}$ & & 5600円 \\
\hline ダイエッツ (サントリー) & $\begin{aligned} & 15 \text { 食 } \\
& 14 \text { 食換等 }\end{aligned}$ & $\begin{array}{l}5,000 \text { 円 } \\
t, 000 円\end{array}$ \\
\hline
\end{tabular}

\section{3. サポートの仕組み}

顧客がダイエットを継続し，成功するため のサポートの仕組みとして, サポートッール が提供され，サポート体制が整備されている。 サポートッールとしては図表ー7 のようなも のが提供される。これは，顧客がダイエット を実施する際の自己管理を支援するためのも のである。これらのツールは，ガイドブック やDVDによってダイエットの方法を知識と

\section{口図表一7}

マイクロダイエットのサポートツール

\begin{tabular}{|c|c|}
\hline サポートツール & 内容 \\
\hline ガイドブック & $\begin{array}{l}\text { ダイエットの実行法,二度と太らない生活習慣 } \\
\text { を三冊のガイドブックでわかりやすく紹介して } \\
\text { いる。 }\end{array}$ \\
\hline ダイアリー & $\begin{array}{l}\text { ダイエット中の毎日の食事や運動、体調の記 } \\
\text { 録をつける日誌 }\end{array}$ \\
\hline $\begin{array}{l}\text { 生活習慣改善 } \\
\text { プラン }\end{array}$ & $\begin{array}{l}\text { 今までの生活と,これから実行したいことを記 } \\
\text { 入することで生活習慣改善の指針とするノー } \\
\text { ト。 }\end{array}$ \\
\hline ダイエットグラフ & $\begin{array}{l}\text { ダイエット中の体重,サイズの変化をチェック } \\
\text { するために記録するグラフ。 }\end{array}$ \\
\hline DVD & $\begin{array}{l}\text { マイクロダイエットのやせるメカニズムやルー } \\
\text { ルを紹介したもの。実際の体験記も紹介され } \\
\text { ている。 }\end{array}$ \\
\hline
\end{tabular}

図表一 8

\begin{tabular}{|c|c|}
\hline サポート体制 & 内容 \\
\hline コールセンター & 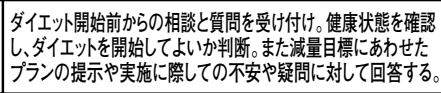 \\
\hline お客様相談室 & $\begin{array}{l}\text { 使用方法、ダイエット中の悩みや相談に対し、 } \\
\text { 専門スタッグアドバイスする。 }\end{array}$ \\
\hline \begin{tabular}{|l} 
マイクロダイエット \\
アドバイザー
\end{tabular} & 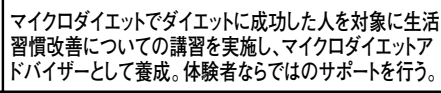 \\
\hline $\begin{array}{l}\text { マイクロダイエットグランプリ } \\
\text { ダイエットサポートセンター }\end{array}$ & $\begin{array}{l}\text { マイクロダイエットグランプリ出場希望者のた } \\
\text { めの定期的なアドバイスイや,成功後の維持に } \\
\text { ついてのサポートを行う。 } \\
\end{array}$ \\
\hline $\begin{array}{l}\text { マイクロダイエット } \\
\text { 正規取扱店 }\end{array}$ & $\begin{array}{l}\text { 薬局,薬店などの正規取扱店のスタッフが、対 } \\
\text { 面でアドイスを行う。 }\end{array}$ \\
\hline
\end{tabular}

して学ぶだけではなく，ダイエットの過程を 日誌やグラフによって自ら記録することによ って，意欲を継続させチベーションを維持さ せることをねらったものである。

サポート体制は図表一8のようになってい る。サニーヘルスや薬局・薬店などのス夕ッ フの他に，マイクロダイエットでダイエット に成功した人をアドバイザーとして養成し， 体験者ならではのサポートを行う体制をとっ ていることが大きな特徴である。

\section{4. プロモーションとコミュニケーション}

マス媒体を利用した広告については, 発売 当初から女性誌を中心としてきた。これは， 先述した MINEのパブリシティ記事が大きな 効果をあげたという経験を踏まえ，主要な夕 ーゲットである若い女性への到達を意図した ものである。さらに，2001 年からテレビ広告 を開始し，特に 2004 年，2005 年は出稿量を 大きく拡大している。また，交通広告を積極 的に活用し，特に車内モニターを広告媒体と して多く利用している。 
毎年 1 回「マイクロダイエット・グランプ リ」を開催している。この催しは, 2002 年か ら開始されたもので，当初は「マイクロダイ エット減量コンテスト」という名称であった。 その後, 名称が変わるとともに開催の主旨や 審査の基準も徐々に変化してきており，単に 体重を減量した度合いを競うのではなく, 健 康的にダイエットし, 内面, 外面が変化して 生活習慣を改善したと認められる人を選考し, 表彰している。2006 年のグランプリの審査の 基準は, どれだけ減量できたかではなく, 生 活習慣をどのように変えられたか，自分の体 験をどのように周囲に伝えることができたか, 内面がどのように変わったかという点となっ ている。応募者は, 書類審査, 面接審査によ って絞り込まれ, 福岡, 大阪, 東京での地区 予選会を経て本選でグランプリが決定される。 グランプリの様子は, 雑誌広告や車内広告, Web サイトなどを通じて伝えられる。

「Microdiet On line」という Webサイト を通じて，さまざまな情報提供を行っている ことも，コミュニケーション活動の大きな特 徵としてあげられる。このサイトでは, ダイ エットの知識に関する情報提供や, 商品の紹 介, 販売も行っている。これらは, 他の多く の商品やブランドのサイトと共通する特徴で あるが，大きな違いは利用者同士の多様な接 点が提供されていることである。

例えば,「みんなのダイエットストーリー」 というコーナーにいき, 自分の身長, 体重, ダイエットの目標などを入力すると, 体験者 のうち自分と似た人を検索することができる。 さらに，その人がどのようなステップでダイ エットに成功したのかというストーリーをみ
ることができる。「成功者から学ぶ 2 週間の使 用例」というコーナーを訪れると，ダイエッ トにつまずきやすい最初の 2 週間について, 成功者の食生活を確認することができる。 「教えて Q\&A」というコーナーでは, 利用者 の質問に対して, 先輩のダイエット成功者が 回答を行っている。

こうした顧客間インタラクションの多様な 仕組みを持っていることが, Microdiet On line の大きな特徴である。さらに, サニーへ ルスではマイクロダイエットを利用してダイ エットに成功したユーザーの中からマイクロ ダイエット・アドバイザーという資格を認定 し，ボランティア的なアドバイザーとして育 成している。こうした仕組みは, マイクロダ イエットの成功者がアドバイザーとなって, 次の成功者を育成し, それがまた次の成功者 をサポートするというものであり, 顧客間の インタラクションが相乗効果を生む仕組みで もある。

(5) 成功要因の考察とマーケティング 戦略上の示唆

\section{1. マイクロダイエットの成功要因}

上述してきたように，マイクロダイエット はカロリー調整型のダイエット食品のパイオ ニアとして，これまでに大きな成功をおさめ てきた。ここでは, マイクロダイエットの成 功の要因を検討するとともに, そこから得ら れるマーケティング戦略上の示唆を整理して いこう。

創業者の西村社長は, 創業当初のダイエッ 
ト・ビジネスの体験を通じて，「ダイエッ ト・ビジネスは物売りではなく，いわば教育 産業である。売りっぱなしではなく, 効果が 出るまで支援していく事業である。」という， ダイエットビジネスに関する強固な事業理念 を有するに至ったという。この理念を土台と し, マイクロダイエットのビジネスを, 商品 の販売ではなく, ダイエット・サポート・シ ステムの販売であると規定した。すなわち， ダイエット食品という商品そのものを販売す るのではなく, ダイエットを効果的に，かつ 安全に続けていくためのシステムを販売する というように，事業の規定を行ったというこ とである。このことが，マイクロダイエット の成功を支えたもっとも根幹の要因であった と考えられる。

それでは, ダイエット食品の販売という事 業規定とダイエット・サポート・システムの 販売という事業規定は, どのような差異をも たらすのだろうか。このケースでは，2つの 大きな違いをもたらしたと考えられる。順に 検討していこう。

ダイエット・サポート・システムと事業を 規定することがもたらした効果のひとつは， 顧客の継続利用を目的としたマーケティン グ・ミックスの有機的連動が図られたことで ある。先述したように, マイクロダイエット の販売価格は, 他の商品に比してかなり高い 水準に設定されている。これは, 商品そのも のだけではなく，さまざまなサポートの仕組 みを含めた価格である。エステティックサロ ン, 薬店・薬局, 電話による通信販売という ようにひろげられてきたチャネルも, 購入時 および購入後のカウンセリングができるとい
う観点から選択された。プロモーションやコ ミュニケーション活動においても, ユーザー の継続への意欲を刺激するという目的にかな りのウェイトが置かれている。

こうしたマーケティング・ミックスが有効 に機能することによって，ユーザーの継続利 用が促進されるが, 継続利用の促進は, さら にさまざまな効果をもたらす。マイクロダイ エットを継続利用することは，利用者にとっ てはダイエットという目的を果たすことにつ ながる。販売元のサニーヘルスにとっても， 利用者の継続利用による収益向上が果たされ， さらには, ダイエットの成功者が増加すると いう実績や成功事例を公開することが新規顧 客獲得や既存顧客の継続利用促進にもつなが ってくるのである。このように，ユーザーの 継続利用の促進はさまざまな相乗効果を生む ことになる。このことは, ダイエット・サポ ート・システムという事業規定のもとでマー ケティング・ミックスが有機的に連動するこ とによってもたらされている。

ダイエット・サポート・システムだと事業 を規定することによる，もうひとつの大きな 効果は, 顧客間インタラクションを可能とす ることである。ダイエット食品の販売業だと 事業を捉える場合には，商品を売った時点で 販売が完結する。この場合には，利用者の利 用状況を把握する必要もないし，把握する必 然性もない。したがって，利用者同士が抦 いのダイエットのプロセスやその結果を知る ことも難しい。これに対し，ダイエット・サ ポート・システムとして事業を捉える場合に は，利用者がダイエットに成功した時点で販 売が完結することになる。この場合には，利 
用者のダイエットのプロセスに関与し，その プロセスを把握することが必要となる。

サニーヘルスが，ユーザーのダイエットの プロセスやその結果を把握することによって, ユーザー相互のインタラクションのためのさ まざまな仕掛けや仕組みをつくることができ る。こうした仕組みによって，ユーザーが成 功者をモデルとしそのやり方を習うことがで きたり，成功者の目標達成へのステップと自 分の過程とを比較することができる。さらに, 自らが他のユーザーのモデルとなるという目 標を設定する顧客もいるかもしれない。この ように, 顧客間インタラクションの仕組みは, ユーザーの意欲やモチベーションの維持に多 大な効果をもたらしていると考えられる。

さらに，上記のような顧客間インタラクシ ヨンの仕組みがうまく機能することによって, これまで自分ひとりの閉じられた世界で行わ れていたダイエットという行為が，他者との 関わりの中に引き上げられたとも考えられる。 この点に関しては，マイクロ・ダイエット・ グランプリが果たした役割が大きいと考えら れるが，いずれにしても，ダイエットという 行為が表舞台に引き上げられたことによって， ダイエットに対する消費者のイメージが，ポ ジティブな方向に少なからず変化したと考え られる。このことは, ダイエット市場そのも のの拡大に対しても大きな影響を与えたと推 測される。

\section{2. ケースから得られる示唆}

ダイエット・ビジネスに限らず，健康関連 ビジネスでは，特定の製品やサービスを利用 してすぐに目に見える効果が得られるという
ことは少ない。ほとんどの製品では，ある程 度の期間にわたって継続利用することによっ て，はじめて効果が実感できる。したがって， 効果が目に見えて表れてこない過程において， いかに継続利用を促進するかということが， 成功のための重要なキーとなる。

マイクロダイエットのケースから得られる， 継続利用促進のための示唆のひとつは, 商品 ではなくサポート・システムの販売だと自ら の事業を位置づけたことに求められる。サニ ーヘルスでは，単にマイクロダイエットとい うダイエット食品を販売するのではなく, マ イクロダイエットはあくまで減量を支援する 一つのツールであり，その他のサポートの仕 組みを含めたサポート・システムとしてマイ クロダイエットを販売している。このため, ダイエットを継続するプロセスの管理も販売 者の責任であると考えてマーケティング戦略 を策定している。このことが，マーケティン グ・ミックスの有機的な連動をもたらし，継 続利用の促進につながったことは，すでに検 討したとおりである。

効果の実感を得にくい利用過程においてい かに継続的な利用を促進するか，ということ がキーとなるビジネスは健康関連ビジネスに 限らないだろう。例えば，教育や習い事に関 連するビジネスの多くも，同様の性質を持っ ているだろう。こうしたビジネスにおいては， 自らの事業をどう規定し，それを土台として どのようにマーケティング・ミックスの有機 的な連動を図るかということが，重要なポイ ントになるはずである。

もうひとつの重要な視点は, マイクロダイ エットの場合，ユーザーの継続利用を促進し 
それを果たすことが，他のユーザーの継続利 用を促進するという相乗効果の仕組みを有し ていることである。マイクロダイエットによ ってダイエットに成功した人が，グランプリ に出場したり，アドバイザーとなったり，日 記を公開するといったことは，新しいユーザ 一の継続利用を刺激する役割を果たしている。 その刺激を受け取って利用を継続した人が, 今度は次のユーザーのモデルとなる。

こうした，継続利用を促進するためのユー ザー間の相乗効果の仕組みを導入することは, 他のビジネスにも大いに参考になるものだと 考えられる。特に今日では, インターネット を効果的に利用することによって，ユーザー 間のコミュニケーションに関する多様な仕組 みを構築することが可能である。それぞれの ビジネスの特徵に適合した, ユーザー間の相 乗効果の仕組みを構築するが, 継続利用促進 のための重要な鍵となる場合も多いだろう。

(6)

おわりに

マイクロダイエットの製品としての特徴は, 「必要な栄養素を含みながら低カロリーのも のを，食事の代わりに利用することによって 摂取カロリーを抑える」というシンプルなも のであり, 以前から同様のコンセプトを有す る競合製品が存在した。ここまで検討してき たように，マイクロダイエットの強みは，製 品とサポートの仕組みが一体となったダイエ ット・サポート・システムを構築しているこ とにあり，これまではこの部分での強力な競 合相手が存在しなかった。
ところが，先述したように，2005 年から 2006 年にかけて有力企業が同様の考え方でカ ロリー調整食品市場に本格的に参入してきた。 これらの企業が採用している, ダイエットを 継続させるためのサポート・システムを充実 させるという方法はマイクロダイエットを習 ったものであり, 先にみたように, ほとんど の製品では価格もマイクロダイエットの $1 / 2$ から $1 / 3$ の水準に設定している。以前とは明 らかに競争環境が変化してきている。

こうした競争環境の変化にマイクロダイエ ットがどのように対応していくかは, 今後の 大きな課題となるだろう。2006 年 2 月に, サ ニーヘルスは, 従来のジュースタイプ, スー プタイプに加えて, リゾット，ゼリー，レト ルトなどの幅広い製品をラインアップに加え た。この他に, マイクロダイエット・サポー ト・シリーズとして, 低カロリーのクッキー やゼリーなどの間食をシリーズ化している。 さらに，エクササイズのためのマシンやシュ ーズなども品そろえに加えている。

先述したように, サニーヘルスでは, ダイ エットに成功したユーザーを育成し，マイク ロダイエット・アドバイザーという資格を認 定するという仕組みをつくっている。このア ドバイザーの育成のための教材を利用して， ダイエット教育のビジネスを立ち上げる計画 ももっているという5

このように, マイクロダイエットを中心と して，ダイエット・サポートを総合的に展開 することが, サニーヘルスの志向する方向だ とみてとれる。マイクロダイエットは 1989 年 に日本で発売して以来, 約 200 万人以上の販 売実績があるという ${ }^{6)}$ 。ダイエットに成功し 
たユーザーもかなりの数にのぼるはずである。 ダイエット・サポート・システムの販売とい う，現在のマイクロダイエットの事業領域に おける競争優位を追求するにしても，総合的 なダイエット・サポート事業への展開を目指 すにしても，顧客間インタラクションの仕組 みが有効に機能する土台となる，分厚い利用 経験者の基盤を持っていることが，マイクロ ダイエットの最も大きな強みとなるはずである。

謝辞：本稿の執筆に際して, サニーヘルス 株広報部の稲田達矢氏にご協力いただいた。 記して謝意を表したい。

注

1）「リエータ」は 2001 年に「バランスダイエット」 という名称で発売されたが, 2005 年にリニューア ルした後に，売上が大幅に伸張した。

2）日本能率協会総合研究所『健康ニーズ基本調査 2004』による。

3）この調査では，肥満度の判定にはBMI（Body Mass Index）を用いている。BMIは，「体重 $\mathrm{kg} \div$ $\left.(\text { 身長 } m)^{2}\right\rfloor$ で算出され, BMI の值が 25 以上の者 を肥満者としている。

4）富士経済『H・B フーズマーケティング便覧 2006 年 No.2』による。

5）サニーヘルス・プレスリリース（2006 年 2 月）に よる。

6）サニーヘルス・プレスリリース（2006 年 2 月）に よる。

\section{参考文献}

IMpress（2002）「お客様の立場に立ったカウンセリン グ販売を実施」『IMpress』2002 年 5 月号。 富士経済（2006）『H・B フーズマーケティング便覧 2006 No. 2 一機能志向食品編』(株)富士経済。

日本能率協会総合研究所 (2004) 『健康ニーズ調査 2004』(株)日本能率協会総合研究所。.

住山正男（1995）『驚異のマイクロダイエット』日之 出出版。

サニーヘルス（2006）『サニーヘルス・プレスリリー ス』サニーヘルス株)，2006 年 2 月。
守口 剛（もりぐち たけし）

1979 年早稲田大学政治経済学部経済学科卒業後, 筑波大学大学院経営・政策科学研究科経営システム 科学専攻, 東京工業大学大学院理工学研究科経営工 学専攻博士課程, 修了。博士 (工学)。財団法人流 通経済研究所, 立教大学社会学部産業関係学科教授 を経て, 現在, 早稲田大学商学部教授。

著書に『プロモーション効果分析』『マーケティン グ・サイエンス入門』(共著)『マーケティング・ハ ンドブック』（共監訳）ほか。

中村 哲（なかむらてつ）

1960 年東京・神田生まれ。 80 年立教大学社会学部 観光学科中退後, 北米・アジア各国を迴り, 各地の 伝承医学や自然療法を研究する。現在, 家業の呉服 悉皆業を継ぐかたわら, 代替医療関係の調査, 執筆 を行う。（有）中むら 代表取締役。 